\title{
PREVALENCE OF CHLAMYDIA-RELATED ORGANISMS WITH ZOONOTIC POTENTIAL IN FARMS OF THE POLTAVA REGION
}

DOI: 10.36740/WLek202006117

\author{
Viktoriya K. Zezekalo, Serhii M. Kulynych, Anatoliy A. Polishchuk, Mokhamed S. Kone, Natalia 0. Avramenko, \\ Yuliia V. Vakulenko, Nataliia V. Chyzhanska \\ POLTAVA STATE AGRARIAN ACADEMY, POLTAVA, UKRAINE
}

\begin{abstract}
The aim of our work was to survey private farms in the Poltava region on the prevalence of Chlamydia-like organisms Waddlia chondrophila and Parachlamydia acanthamoebae. Materials and methods: The PCR research was conducted in 2018-2019 at the Institute of Pig Breeding and Agro-industrial production of the NAAS. The study materials were 300 vaginal scrapings of cows and 28 samples of clinical material of pigs and boars with a suspicion of a chlamydial infection, which were selected at private farms in the Poltava region. Results: Chlamydia-like bacteria Waddlia chrondophila DNA was detected in 132 (44\%) samples taken from cows and 8 (28.6\%) samples from pigs and boars. Parachlamydia acanthamoebae DNA was not detected in pig samples. However, 43 (14.3\%) clinical samples taken from cows were found to be Parachlamydia acanthamoebae - positive. 9 (3\%) cows and 2 (7.14\%) pigs turned out to be Chlamydia spp. - positive (the samples contained DNA of bacteria of the family Chlamydiaceae).

Conclusions: Our data indicate a relatively high prevalence of Chlamydia-like bacteria in problematic as to chlamydial infection farms in the Poltava region. Chlamydial infection carry a zoonotic threat, therefore it is necessary to observe safety and personal hygiene measures when working with animals. In addition, it is necessary to carry out periodic screening among the population with reproductive disorders and in occupational risk groups, periodic monitoring in livestock farms, to avoid the consuming the unpasteurized milk, and thermally unprocessed meat.
\end{abstract}

KEY WORDS: Parachlamydia acanthamoebae, Waddlia chrondophila, PCR, cattle, pigs

Wiad Lek. 2020;73(6):1169-1172

\section{INTRODUCTION}

Chlamydial infection is a group of infectious diseases caused by Gram-negative obligate bacteria of order Chlamydiales, differ in the source of infection, transmission mechanism, pathogenesis and clinical manifestations. Zoonotic chlamydial infection is an important public health problem and has clinical and epidemiological significance both in humane and veterinary medicine throughout the world, for its global distribution, negative impact on public health and the associated economic losses. 70 years of searching for an effective vaccine have not given the intended effect [1], therefore periodic screening researches followed by treatment with antibiotics are the main prevention of chlamydial infection. The species laboratory diagnosis of zoonotic chlamydial infection remains unsatisfactory, as commercially available tests are focused solely on the detection of bacteria of the genus Chlamydia, leave out of consideration Chlamydia-like bacteria. However, the State Statistics Service of Ukraine reports that during a preventive examination and other types of dispensary work in 2018, the number of patients identified among the first-ever established chlamydial infection diagnosis was $47.5 \%$, which indicates a high prevalence of chlamydial infection among the population of Ukraine. According to the State Statistics Service, the level of diagnosed female and male infertility in the regions of Ukraine by 2018 ranges from $19.31 \%$ (female) and $14.05 \%$ (male) in the Zaporizhzhia region to $1.34 \%$ (female) in the Luhansk region, and to $0.08 \%$ (male) in the Kyiv region, such a range of fluctuations indicates the incomplete registration of data [2].

Waddlia chondrophila [3-5] and Parachlamydia acanthamoebae [6-10] are the most well-known and best-studied representatives of Chlamydia-related bacteria that associate with reproductive disorders and diseases of the respiratory system in both humans and animals. In addition, Waddlia chondrophila has a negative impact on reproductive system of men, in particular, on human spermatozoa [11]. It is believed that consuming thermally untreated milk and meat, contact with animals may be potential routes of infection for W. chondrophila and P. acanthamoebae, as well as possible transmission from mother to child (during pregnancy, childbirth and breastfeeding) $[12,13]$. The Chlamydia-related bacteria $W$. chondrophila and $P$. acanthamoeba are endosymbionts of amoebas that is their feature. The ability to infect free-living amoeba makes these species extremely resistant to environmental stress factors and disinfectants. The prevalence of free-living amoeba can lead to Chlamydia-related bacteria $W$. chondrophila and P. acanthamoebae and amoeba entering the water supply system $[14,15,15,16,16]$. All this should cause concern due to the fact that in Ukraine there is a 
tradition of consuming thermally unprocessed lard of pigs and unpasteurized "fresh" milk, and people living in small localities do not have access to central water supply and sanitation.

Products of pig and dairy cattle breeding are of great importance for society, it is the main source of meat, milk, dairy products, clothing, and fertilizers for crops. The hybrid war and the associated economic instability increased the level of impoverishment of the population of Ukraine, led to the growth of socially vulnerable groups and the spread of the illegal street trading [17]. The State Service of Ukraine on Food Safety and Consumer Protection in different regions is sounding the alarm, however, a significant difference in food prices in supermarket chains and the illegal street markets makes such markets attractive for rapidly growing socially vulnerable groups of the population.

\section{THE AIM}

The aim of our work was to survey private farms in the Poltava region on the prevalence of Chlamydia-like bacteria Waddlia chondrophila and Parachlamydia acanthamoebae.

\section{MATERIALS AND METHODS}

Experimental researches were carried out during 2018 2019 in the Animal Health Laboratory and the Laboratory of Genetics and Breeding of the Institute of Pig Breeding and Agro-industrial production of the NAAS (Certificate of compliance of the measuring system state No. 021-19 dated 31 January, 2019). The researches materials were 300 clinical samples of biological material (vaginal scrapings) of cows and 28 samples of biological material of pigs and boars (epithelial scrapings from the rectum or prepuce from males and vaginal scrapings from females), suspected of chlamydial infection and selected at private farms in the Poltava region. Animals for research were selected by agreement of farmers for diagnostic purposes. Manipulations with animals were carried out in accordance with the European Convention for the Protection of Vertebrate Animals used for Experimental and other Scientific Purposes, and the General Ethical Principles of Animal Experiments. The permission to use animals is approved by the Bioethics Committee of the Poltava State Agrarian Academy.

Samples were tested by polymerase chain reaction using "Thermo Fisher Scientific" (USA) kits according to manufacturer's instructions. The oligonucleotide primers used in research were made to our order by Metabion international AG, (Federal Republic of Germany) (Table I).

DNA was isolated by "DNA express" kit, Lytech Ltd (Russian Federation). A programmed Tercic- 2 thermostat (DNA Technology, Russian Federation) was used to amplify DNA with annealing conditions of $60^{\circ} \mathrm{C}$. A horizontal electrophoresis system (Cleaver Scientific Ltd, United Kingdom) was used to separate PCR products using $2 \%$ agarose gel electrophoresis in $1 \times$ TBE buffer at a current of $50 \mathrm{~mA}$. The gel was stained with an ethidium bromide solution $(10 \mathrm{mg} / \mathrm{cm} 3)$ and the result was documented using a gel documentation system (Cleaver Scientific Ltd, United Kingdom). The DNA of plasmid pUC19 hydrolyzed with Msp I endonuclease was used as molecular weight marker.

The control DNA samples of Parachlamydia acanthamoebae strain "Berg17" and "Bn9" kindly provided by Dr. Michel Rolf (Central Military Hospital Koblenz, Federal Republic of Germany, Dept. Pathology), DNA of Parachlamydia acanthamoebae strain Hall obtained from Prof. Gilbert Greub (l'Institut de Microbiologie Médecin chef des laboratoires de microbiologie diagnostique Institut de microbiologie del'Université de Lausanne), and Waddlia chrondophila DNA samples obtained from Dr. Christiane Schnee (Institut für molekulare Pathogenese, Jena, Federal Republic of Germany) were used as positive controls.

The identity of the resulting PCR product was additionally verified by restriction analysis, which used the endonucleases produced by "Thermo Fisher Scientific" (USA) (table II), according to the manufacturer's instructions:

\section{RESULTS AND DISCUSSION}

As a result of studies of 300 vaginal scrapings from cows and 28 samples of biological material from pigs and boars suspected of chlamydial infection, taken at private farms in the Poltava region, Chlamydia-like bacteria W. chrondophila DNA was detected in 132 (44\%) samples taken from cows and 8 (28.6\%) samples from pigs. Parachlamydia acanthamoebae DNA was not detected in pig samples. However, 43 (14.3\%) clinical samples taken from cows were found to be Parachlamydia acanthamoebae - positive. 9 (3\%) cows and 2 (7.14\%) pigs turned out to be Chlamydia spp. - positive (the samples contained DNA of bacteria of the genus Chlamydia). (Table III).

Restriction analysis of PCR products using endonuclease Hin1II and DpnII produced fragments of the expected size, proving the identity of the PCR products.

Waddlia chondrophila was first isolated by Dilbeck et al. in 1990 in the United States from aborted cow fetus research, after which the association of DNA presence in samples from humans and ruminants with reproductive disorders was proved [3-5, 24, 25]. Parachlamydia acanthamoebae was first isolated by Michel et al. in swab from a human nose [26], this species is associated with inflammatory processes of the respiratory system and the reproductive organs of humans and ruminants $[6,12,25$, $27,28,28]$. Research on the prevention of Chlamydia-like bacteria in farms in Ukraine is carried out for the first time, so the results of our research can be compared only with the data of European researchers. Various scientists point at the different prevalence of Chlamydia-like organisms in cattle due to abortions in ruminants, for example, Barkallah, M., et al. found about $8 \%$ of $W$. Chondrophila positive samples $[25,29]$, and in 2007 Borel et al. found more than $60 \%$ of $P$. acanthamoebae positive samples taken from cattle with miscarriages [6]. The obtained data on the absence of $P$. acanthamoebae or it insignificant amount in samples from pigs coincide with the data of research conducted in $\mathrm{Eu}-$ 
Table I. The structure of oligonucleotide primers used in research.

\begin{tabular}{ccc}
\hline Species & Sequence & Product size \\
\hline Chlamydiaceae spp [18] & CHMOSPF:AGGTGAGTATGAAAAAACTC & 221 b.p. \\
\hline \multirow{2}{*}{ Waddlia chondrophila [19] } & CHMOSPR:TCGAAAACATAATCTCCGTA & 123 b.p. \\
\hline \multirow{2}{*}{ Parachlamydia acanthamoebae [20] } & WADCHOR:CCTCTCTAGCACCATATCCGG & 88 b.p. \\
\hline
\end{tabular}

Table II. Restriction endonuclease used in research.

\begin{tabular}{ccccc} 
Species & \multicolumn{2}{c}{ Restriction endonuclease } & \multicolumn{2}{c}{ Restriction fragment, b.p. } \\
\hline Waddlia chondrophila (123 b.p.) & Hin 1/l & CATG $\downarrow$ & 53 & 70 \\
\hline Parachlamydia acanthamoebae (88 b.p.) & Dpnll & $\downarrow$ GATC & 31 & 57 \\
\hline
\end{tabular}

Table III. Research results.

\begin{tabular}{|c|c|c|c|c|c|c|}
\hline $\begin{array}{l}\text { Animal } \\
\text { species }\end{array}$ & 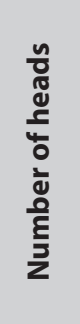 & 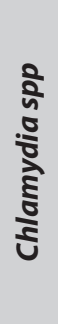 & $\begin{array}{l}0 \\
\frac{5}{5} \\
\frac{0}{0} \\
\frac{0}{0} \\
0 \\
0 \\
\frac{0}{5} \\
\frac{0}{5} \\
\frac{0}{0} \\
5\end{array}$ & 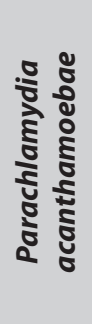 & $\begin{array}{l}\text { Chlamydia-like bacteria } \\
\text { DNA detected } \%\end{array}$ & $\begin{array}{l}\text { Bacteria DNA of the genus } \\
\text { Chlamydia detected } \%\end{array}$ \\
\hline Cattle & 300 & 9 & 132 & 43 & 58,33 & 3 \\
\hline Pigs & 28 & 2 & 8 & 0 & 28,57 & 7,14 \\
\hline
\end{tabular}

rope [30, 31], however, information on the detection of $W$. chondrophila DNA in pig samples was not available to us.

Our research data differ from European scientists, this difference is most likely due to the difference in keeping conditions and different approaches for the prevention of chlamydial infection in pig and dairy cattle.

In 2014 the infection rate with chlamydial species belonging to the genus Chlamydia in Ukrainian pig breeding amounted to $71 \%[21,22]$, in dairy cattle breeding $-28-43 \%$ [23]. The comparably lower prevalence of chlamydia in the under study farms among pigs at the level of 7.14\% and cows $3 \%$ is associated with preventive measures to improve the livestock population, which consist of periodic screening aimed at detecting only bacteria of the Chlamydiaceae family, followed by culling or treatment of chlamydia-positive animals.

\section{CONCLUSIONS}

Our data indicate a relatively high prevalence of Chlamydia-like bacteria in problematic as to chlamydial infection farms in the Poltava region. Chlamydial infection carry a zoonotic threat, therefore it is necessary to observe safety and personal hygiene measures when working with animals. In addition, it is needed to carry out periodic screening among the population with reproductive disorders and in occupational risk groups, periodic monitoring in livestock farms, to avoid the consuming the unpasteurized milk, and thermally unprocessed meat.

\section{REFERENCES}

1. Phillips S., Quigley B.L., Timms P. Seventy Years of Chlamydia Vaccine Research - Limitations of the Past and Directions for the Future. Front Microbiol. 2019;10:70. doi: 10.3389/fmicb.2019.00070

2. Medical Statistics Center of Ukraine data for 2018. [accessed 2 Mar 2020] Available from: http://medstat.gov.ua/ukr/MMXVIII.html

3. Baud D., Goy G., Osterheld M-C. et al. Role of Waddlia chondrophila Placental Infection in Miscarriage. Emerg Infect Dis. 2014;20(3):460-4. doi: 10.1093/cid/cir205

4. Baud D., Goy G., Osterheld M-C. et al. Waddlia chondrophila: from bovine abortion to human miscarriage. Clin Infect Dis Off Publ Infect Dis Soc Am. 2011;52(12):1469-71. doi: 10.3201/eid2003.131019

5. Baud D., Thomas V., Arafa A. et al. Waddlia chondrophila, a potential agent of human fetal death. Emerg Infect Dis. 2007;13(8):1239-43. doi: 10.3201/eid1308.070315

6. Borel N., Ruhl S., Casson N. et al. Parachlamydia spp. and related Chlamydia-like organisms and bovine abortion. Emerg Infect Dis. 2007;13(12):1904-7. doi: 10.3201/eid1312.070655

7. Greub G. Parachlamydia acanthamoebae, an emerging agent of pneumonia. Clin Microbiol Infect Off Publ Eur Soc Clin Microbiol Infect Dis. 2009;15(1):18-28.

8. de Barsy M., Greub G. Waddlia chondrophila: from biology to pathogenicity. Microbes Infect. 2013;15(14-15):1033-41. doi: 10.1111/j.1469-0691.2008.02633.x

9. Verweij S.P., Kebbi-Beghdadi C., Land J.A. et al. Waddlia chondrophila and Chlamydia trachomatis antibodies in screening infertile women for tubal pathology. Microbes Infect. 2015;17(11-12):745-8. doi: 10.1016/j.micinf.2015.09.019 
10. Haider S., Collingro A., Walochnik J. et al. Chlamydia-like bacteria in respiratory samples of community-acquired pneumonia patients: Chlamydia-like bacteria in CAP patients. FEMS Microbiol Lett. 2008;281(2):198-202. doi: 10.1111/j.1574-6968.2008.01099.x

11. Baud D., Vulliemoz N., Ammerdorffer A. et al. Waddlia chondrophila, a Chlamydia-related bacterium, has a negative impact on human spermatozoa. Hum Reprod OxfEngl. 201801;33(1):3-10. doi: 10.1093/humrep/dex342

12. Ammerdorffer A., Stojanov M., Greub G. et al. Chlamydia trachomatis and chlamydia-like bacteria: new enemies of human pregnancies. Curr Opin Infect Dis. 2017;30(3):289-96. doi: 10.1097/QC0.0000000000000369

13. Baud D., Goy G., Gerber S. et al. Evidence of maternal-fetal transmission of Parachlamydia acanthamoebae. Emerg Infect Dis. 2009;15(1):120-1. doi: 10.3201/eid1501.080911

14. van Dooremalen W.T.M., Learbuch K.L.G., Morré S.A. et al. Limited presence of Waddlia chondrophila in drinking water systems in the Netherlands. New Microbes New Infect. 2020;34:100635. doi: 10.1016/j. nmni.2019.100635

15. Michel R., Steinert M., Zoller L. et al. Free-living amoebae may serve as hosts for the Chlamydia-like bacterium Waddlia chondrophila isolated from an aborted bovine foetus. Acta Protozool. 2004;(43(1)):37-42.

16. Dupuy M., Berne F., Herbelin P. et al. Sensitivity of free-living amoeba trophozoites and cysts to water disinfectants. Int J Hyg Environ Health. 2014;217(2-3):335-9. doi: 10.1016/j.ijheh.2013.07.007

17. Dzhafarova M.V., Shevchuk T.A., Kalinovskaya Y.O. et al. Economic Security Of Ukraine: Economic And Legal Aspect. Financ Credit Act Probl Theory Pract. 2019;3(30):78-84. doi: 10.18371/fcaptp.v3i30.179511

18. Ksonz I.M., Pocherniaiev K.F. Sposib vyznachennia dnk bakterii rodyny chlamydiaceae u polimeraznii lantsiuhovii reaktsii shliakhom amplifikatsii frahmenta hena holovnoho bilka membrany (momp). [A method for determining DNA bacteria of the Chlamydiaceae family in a polymerase chain reaction by amplifying a fragment of a major membrane protein (M0MR) gene.UA51635, 2010. p. 2. KsonzI.M. Pochernyaev K.F.] [accessed 2 Mar 2020] Available from: http://uapatents.com/2-51635-sposibviznachennya-dnk-bakterijj-rodini-chlamydiaceae-u-polimeraznijjlancyugovijj-reakci-shlyakhom-amplifikaci-fragmenta-gena-golovnogobilka-membrani-momr.html (In Ukrainian)

19. Zezekalo V.K., Pedera S.B., BuslikT.V. et al. PCR-test for identification and species differentiation of Waddlia chondrophila. Sci Messenger LNU Vet Med Biotechnol. 2019;21(93):143-8. doi: 10.32718/nvlvet9325

20. Zezekalo V.K., Peredera S.B., Buslik T.V. et al. PCR-test system specific identification Parachlamydia acanthamoebae. Sci Messenger LNU Vet Med Biotechnol. 2018;20(92):101-4. doi: 10.32718/nvlvet9220

21. Ksonz I.M. Epizootychnyi stan shchodo khlamidiinoi infektsii u pleminnomu svynarstvi. [Epizootic status of Chlamydial infection in pig breeding]. Agricultural science journal. 2014;(10):34-6. (In Ukrainian)

22. Ksonz I.M. Rol knuriv-plidnykiv u poshyrenni khlamidiinoi infektsii. [The role of producer boars in the spread of chlamydial infection]. Agricultural science journal. 2015;31-3. (In Ukrainian)

23. Milanko 0.0., Avramenko N.0. Kliniko-epizootolohichni aspekty khlamidiozu velykoi rohatoi khudoby. [Clinical and epidemiological aspect of cattle chlamydia]. Bulletin. Of Poltava state agrarian academy 2011;(4):105-7. (In Ukrainian)

24. Dilbeck P.M., Evermann J.F., Crawford T.B. et al. Isolation of a previously undescribed rickettsia from an aborted bovine fetus. J Clin Microbiol. 1990;28(4):814-6. PMCID: PMC267805

25. Barkallah M., GharbiY., Hassena A.B. et al. Survey of infectious etiologies of bovine abortion during mid- to late gestation in dairy herds. PloS One. 2014;9(3):e91549. doi: 10.1371/journal.pone.0091549
26. Michel R., Hauröder-Philippczyk B., Müller K-D. et al. Acanthamoeba from human nasal mucosa infected with an obligate intracellular parasite. Eur J Protistol. 1994;30(1):104-10.

27. Barati S., Moori-Bakhtiari N., Najafabadi M. et al. The role of zoonotic chlamydial agents in ruminants abortion. Iran J Microbiol. 2017;9(5):288-94. PMCID: PMC5748448

28. Wheelhouse N., Longbottom D., Willoughby K. Chlamydia in cases of cattle pneumonia in Scotland. Vet Rec. 2013 Jan 26;172(4):110. doi: 10.1136/vr.f469

29. Dilbeck-Robertson P., McAllister M., Bradway D. et al. Results of a New Serologic Test Suggest an Association of Waddlia Chondrophila with Bovine Abortion. J Vet Diagn Invest. 2003;15(6):568-9. doi: 10.1177/104063870301500609

30. Van Gils M., Aeby S., Vanrompay D. et al. Absence of Chlamydia-like organisms in pigs. New Microbes New Infect. 2015;7:31-2. doi: 10.1016/j.nmni.2015.04.007

31. Di Francesco A., Baldelli R., Donati M. et al. Evidence for Chlamydiaceae and Parachlamydiaceae in a wild boar (Sus scrofa) population in Italy. Vet Ital. 2013;49(1):119-22. PMID: 23564593

\section{Acknowledgments:}

We express our sincere gratitude to the scientists, who have supported and mentored our studies: Dr. Michel Rolf, Dr. Gilbert Greub, Dr. Christiane Schnee, Dr.Igor Ksonz, thanks to whom it became possible to carry out our research.

\section{Funding:}

This research was partially supported by the National academy of agrarian sciences of Ukraine, grant $0119 U 000445$.

\section{ORCID and contributorship:}

Viktoriya K. Zezekalo - 0000-0003-1430-813X ${ }^{A, B}$

Serhii M. Kulynych - 0000-0003-1660-643X ${ }^{E}$

Anatoliy A. Polishchuk - 0000-0003-3572-8491 ${ }^{F}$

Mokhamed S. Kone - 0000-0002-0828-6619 ${ }^{B}$

Natalia O. Avramenko - 0000-0002-1920-5757 D

Yuliia V. Vakulenko - 0000-0002-6315-0116 ${ }^{\mathrm{C}}$

Nataliia V. Chyzhanska-0000-0002-9398-4859 ${ }^{D}$

\section{Conflict of interest:}

The Authors declare no conflict of interest.

\section{CORRESPONDING AUTHOR Viktoriya K. Zezekalo}

Poltava State Agrarian Academy

Skovorody St, 1/3, 36000, Poltava, Ukraine

tel: +380956455626

e-mail: v.zezekalo@gmail.com

Received: 28.02.2020

Accepted: 04.05.2020 